食中毒に関する理論疫学的研究

1. いわゆる集団値について

光崎研一*

\title{
Theoretic Epidemiological Study on Food Poisoning
}

1. The Epidemic Index of Food Poisoning

\author{
Kenichi KOHZAKI
}

Azabu University , School of Veterinary Medicine

1-17-71, Fuchinobe, Sagamihara, Kanagawa 229, Japan

\begin{abstract}
Summary
Annual reports on food poisoning published by the Ministry of Health and Welfare from 1952 to 1988 were used as data sources. Efficacy and availability were discussed based on the results obtained from the epidemiological statistical index of the epidemic index. The following results were obtained :

1. The epidemic index showed an L-form distribution, such as the light half of the normal distribution.

2. The epidemic index transformed to logarithmic or square root showed normal distribution.

3. Trends and seasonal variation were observed in occurrence of food poisoning by least squares method.
\end{abstract}

食中毒統計において，厚生省は1979年以降，1952 年に遡り「「1件当たりの患者数」を官庁統計として 公表しているが, すでに山田ら ${ }^{11} は, 1958$ 年, 食中毒 1 件当たりの患者数を「集団値」と名付け, 食中毒 流行の強度を表わす統計量とし, 流行解析に使用し た。

著者は, この「集団値」を, 食中毒流行の理論疫 学的解析に利用することを考之，まず，その分布型 について検討した。

* 麻布大学獣医学部 于229 神奈川県相模原市㴊野辺1-17-71

\section{瓷料および方法}

「厚生省大臣官房局統計情報部編：食中毒統計 $(1952 \sim 1988)\rfloor^{11}$ から年次ごとの月別「集団值 $\rfloor^{2,10}$ を求め, その生デー夕, 対数および $2 \sim 6$ 乗根変換 值 ${ }^{4}$ の平均值, 標準偏差, 変動係数, 歪度および尖 度 ${ }^{5 \sim 8)}$ を計算し,「集団值」の分布の正規性を検討し た。

これらの生および各種変換値を横軸にとり, 对応 する例数を, 縦軸にとり, それぞれのヒストグラム を作成した。さらに正規確率紙を使用して分布の正 規性の検定を行った。

一方，流行数，患者数および集団值の年次別平均 
表 1 食中毒集団値444例の生および各種変換値の基本統計量

\begin{tabular}{|c|c|c|c|c|c|c|c|}
\hline 変 換 & 生データ & 对数 & 平方根 & 3 乗根 & 4 乗根 & 5 乗根 & 6 乗根 \\
\hline 平均 值 & 30.161 & 1.373 & 5.181 & 2.953 & 2.241 & 1.902 & 1.706 \\
\hline 標準偏差 & 22.340 & 0.322 & 1.824 & 0.697 & 0.399 & 0.273 & 0.210 \\
\hline 変動係数 & 74.07 & 23.46 & 35.20 & 23.59 & 17.82 & 14.34 & 12.33 \\
\hline 歪度 $\left(\beta_{1}=0\right)$ & $2.573^{* *}$ & $-0.587^{* *}$ & $0.179^{* *}$ & $0.330^{* *}$ & 0.103 & -0.034 & $-0.301^{* *}$ \\
\hline 尖度 $\left(\beta_{2}=3\right)$ & $16.851^{* *}$ & $3.886^{* *}$ & $4.801^{* *}$ & $3.770^{* *}$ & $3.555^{* *}$ & $3.512^{*}$ & $4.179^{* *}$ \\
\hline
\end{tabular}
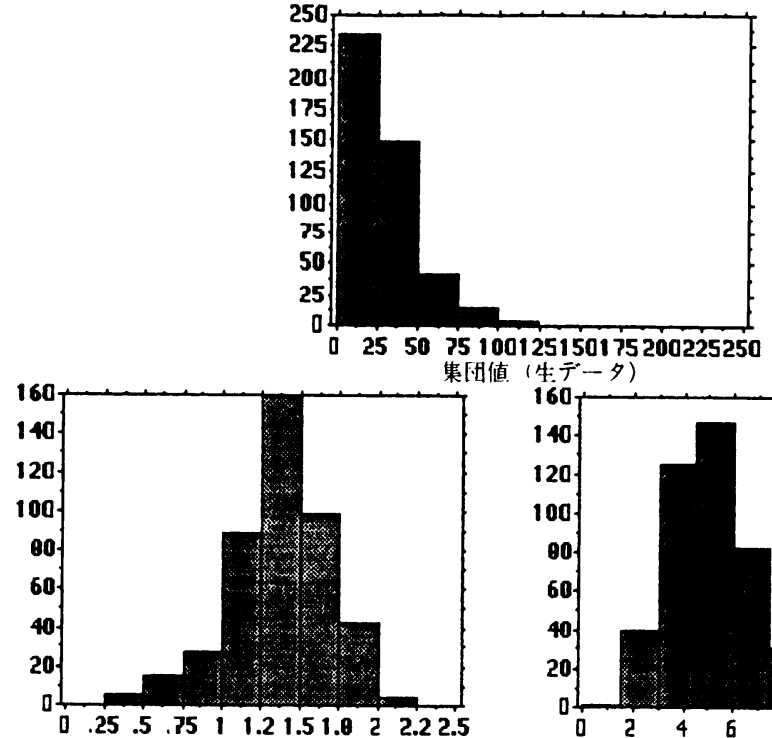

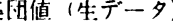
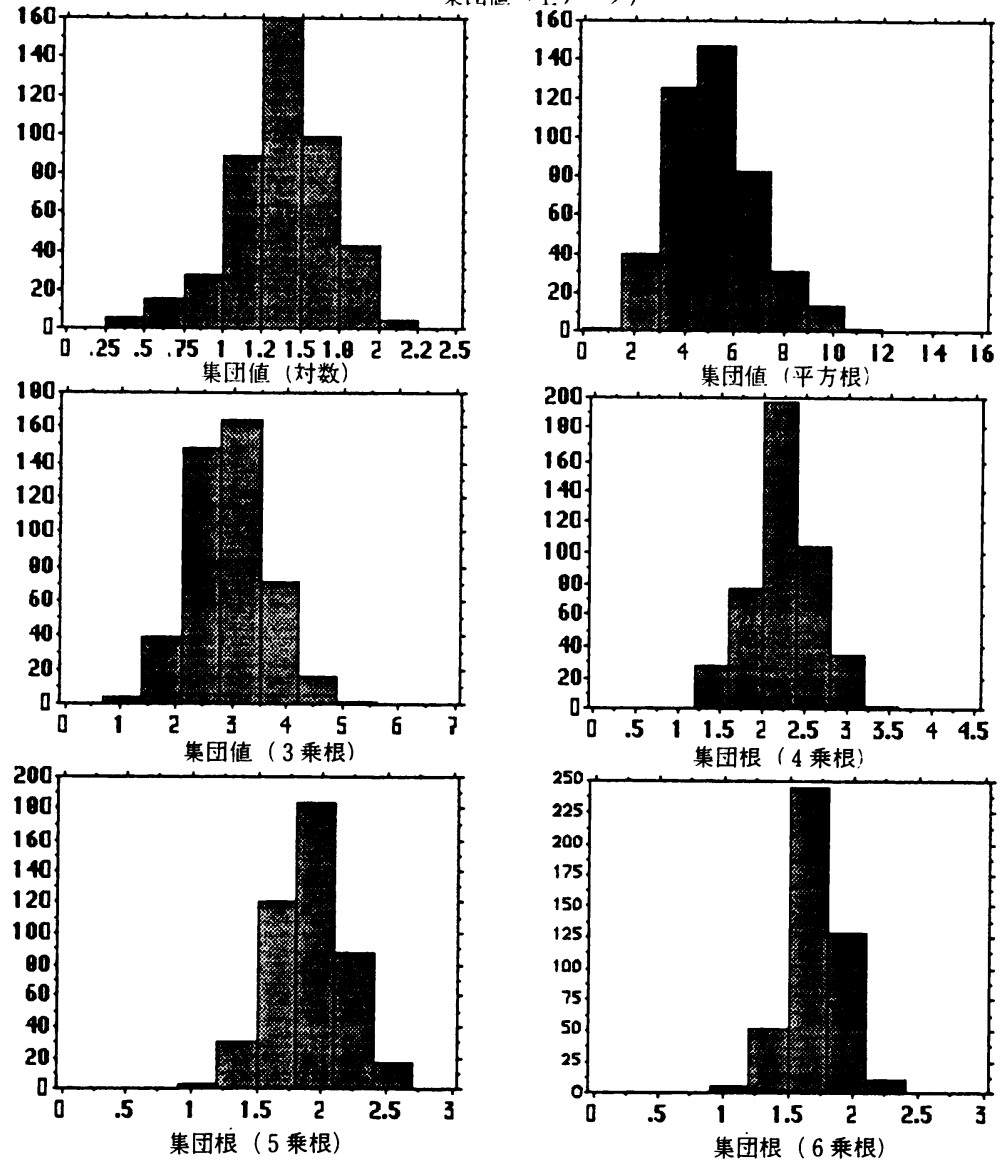

図 1 生および各種変換した集団値の分布 
分布曲線を描き，最小二乗法により，各曲線の時系 列変化すなわち傾向変動および季節変動3,9,12)を検討 した。

\section{成}

1952～1988年（37年間）の食中毒流行数は 53,482 件，その患者数は $1,286,081$ 人であり，これらから求 めた年次ごとの集団值は444例である。表 1 に, 生お よび各種変換した集団值の基本統計量を示した。デ 一夕が正規分布する場合，歪度は 0 ，尖度は 3 にな る。表 1 に示したように，4および 5 乗根変換値を 除き，いずれも $1 \%$ の危険率で歪度 $=0$ の仮説が棄 却されている。また，5乗根変換は $5 \%$ の危険率で，
他は $1 \%$ の危険率で，尖度 $=3$ の仮説が充却されて いる。したがって，いずれの值も分布の正規性が棄 却されている。

図 1 に，集団値の生および対数，2６乗根変換 値のヒストグラムを示した。 $3 \sim 5$ 乗根変換値の場 合，中央值に対してほぼ左右対称であり，正規型に 近い分布を示している。

図 2 に，集団値の生および対数，2６乗根変換 值を使用した正規確率紙による分布の正規性の検定 結果を示した。数個の点を除き，いずれの場合もほ ぼ 1 直線上に点が乗っている。詳細に観察すると, 正規確率紙上部の数個の点は, すべて異常流行によ るものである。したがって，数值変換後の容易さを

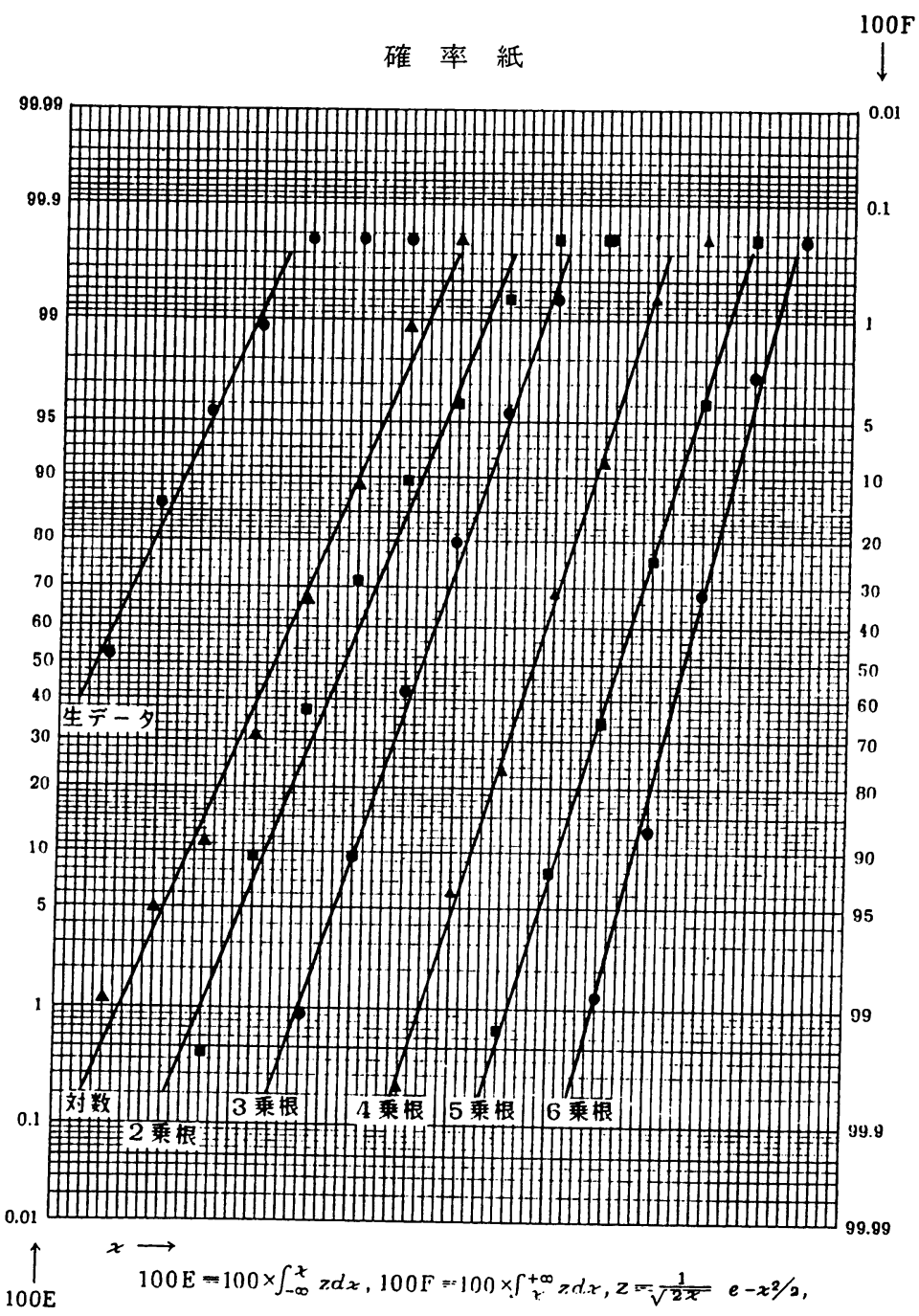

図 2 生および各種変換した集団値の正規確率紙による分布型の検討 
考虑すれば，「集団値」を对数変換または平方根変換 すれば食中毒流行の理論疫学的解析に利用可能であ る。

図 3 に，年次ごとの月別流行数，患者数および集

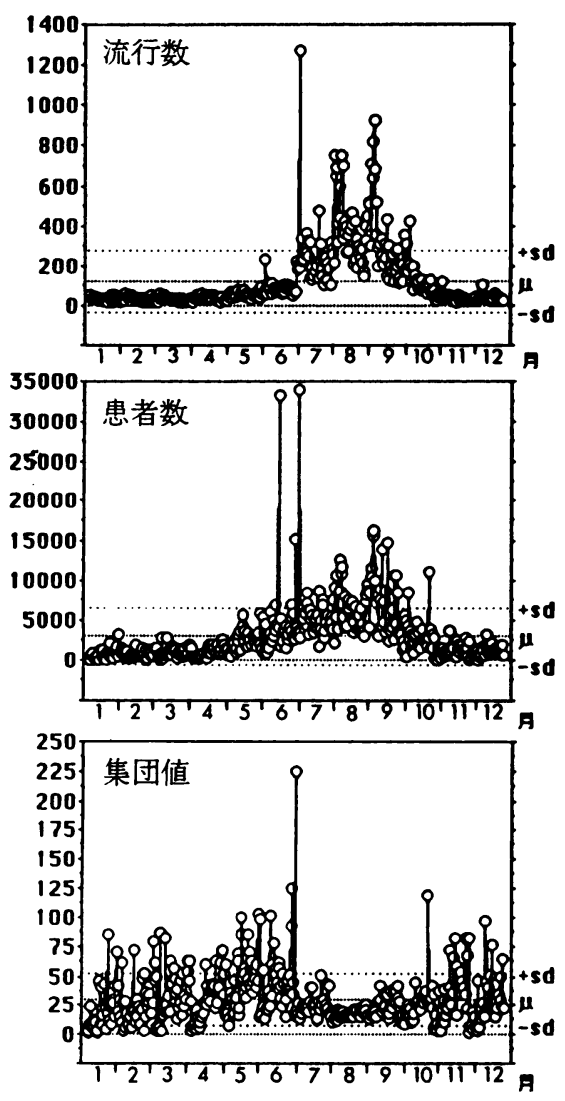

図 3 流行数・患者数・集団値の月別 (年次別) 推移

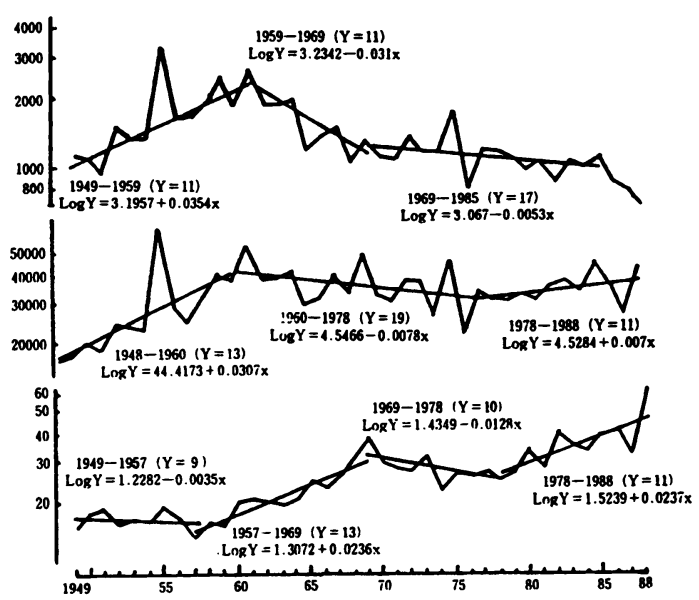

図 4 集団值の傾向変動
団值（無変換）を，横軸に月をとり，同一の月ごと に重ねた月別推移を示した。流行数および患者数の 推移は，6－9月の頃に高く，時によって異常に高 い值が散発している。これに対し，集団地の推移は， 6〜10月の頃に低い值が密発するが， 1 2 月, 3 ～ 5 月および11 12月に，比較的高い値を示してい る。

図 4 に，最小二乗法で求めた流行数，患者数およ び集団值の傾向変動を示した。集団値の傾向変動は, 4 期に別れるように見える。

図 5 に，傾向変動の各期について，各期毎の季節 変動を示した。各期とも，ほほ 6 月に最高値が，ま

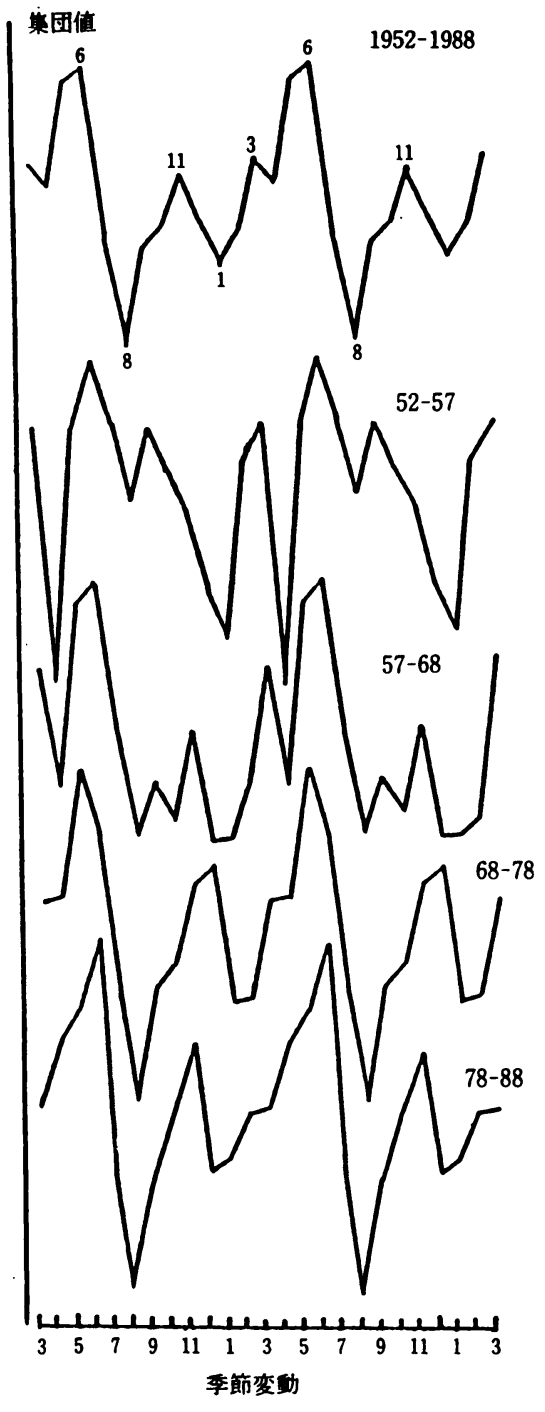

図 5 集団値の季節変動 
た 8 月前後に最低值が現われている。また各期とも， 3 および11月に比較的高い值を示している。しかし， 全観察期の後半になると，3月の山が消滅し，11月 に山が現われている。
図 6 に,「集団値」の年次別推移を，5人間隔で21 階級に分割して示した。集団 $25($ 人)以下の階級が全 体の $2 / 3$ を占め, 101 (人) 以上の階級が $8.8 \%$ であっ た。

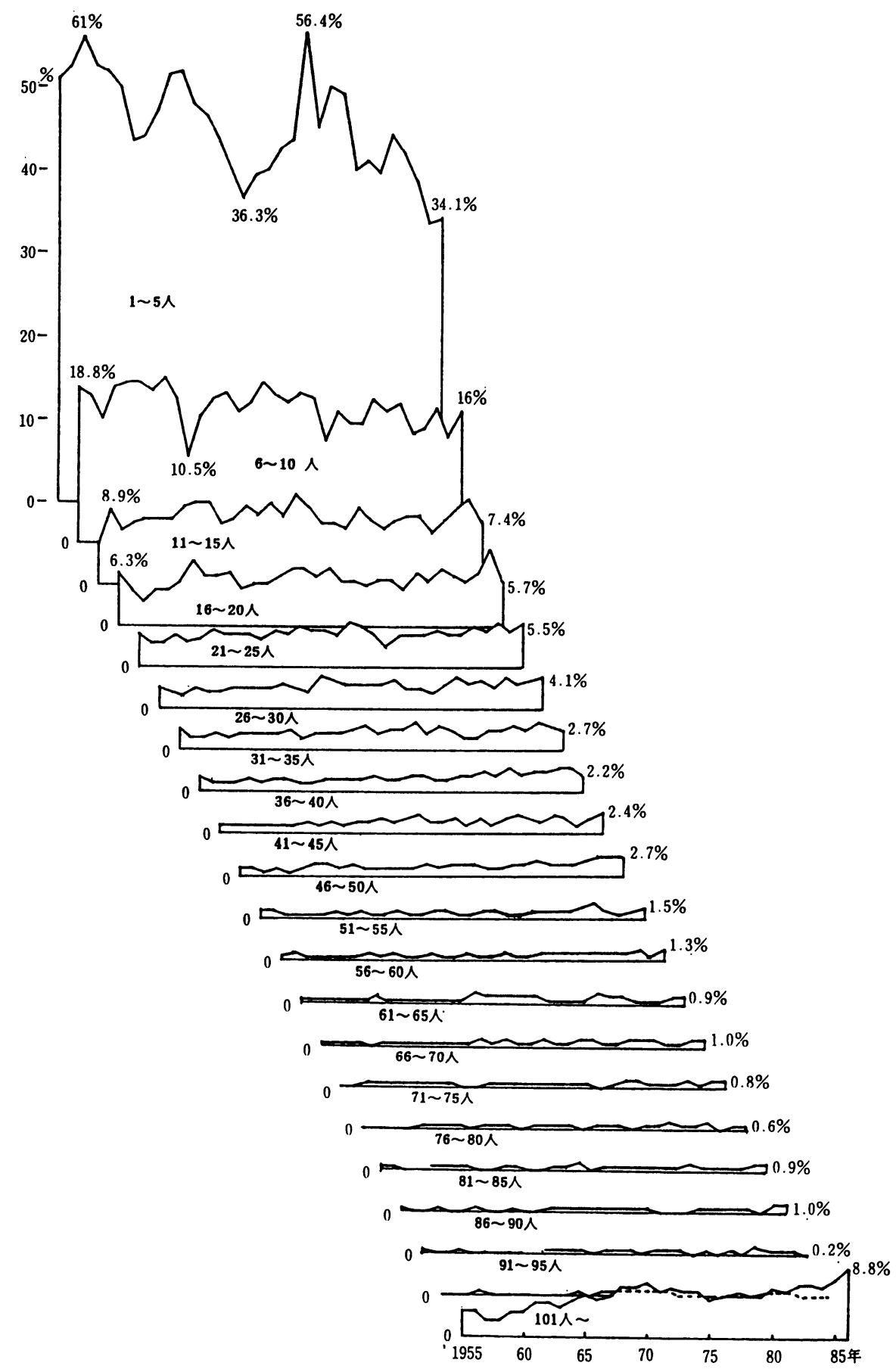

図 6 階級別集団值の年次分布（\%） 


\section{考察}

食中毒流行を理論疫学的に解析する場合, 流行の 強さを表わすパラメー夕が近似的にでも正規分布す れば，流行の解析が容易になる。

供試資料" から求めた444例の「集団値」およびそ の各種変換値の分布型を検討した結果，「集団値」を 对数変換または平方根変換すれば，近似的に正規分 布する。集団值は食中毒流行の理論疫学的解析に有 用なパラメーターになると思われる。ただし，近似 的に正規分布するため，どの程度まできびしい検定 に耐えるか，まだ不明である。この点については， 今後, 経験的に立証することが必要と思われる。

食中毒の集団值の月別推移は，流行数および患者 数のそれと著明な違いがある。集団値では，7～9 月に最低值が現われ，「集団」中毒が少ないことを示 している。食中毒の流行は, 微生物学的に解釈され る消化器系伝染病の流行とは異なる。むしろ社会科 学的, 人間行動学的, あるいは医学生態学的に考察 寸ることが, 食中毒の真の疫学的構造を探るために 必要である。

5 人単位で, 21 階級に区分した食中毒流行数の年 次別百分率で見たように，食中毒の 3 分の 2 は 25 (人) 以下の集団で発生し, 100 (人) 以上の集団にお ける発生例は $9 \%$ にすぎない。単純平均は約 30 (人) の集団のため将来は25(人) 前後, 50 (人) 前後, 100 (人)前後およU゙ 200 (人) 以上の集団の流行が, 疫 学上重要な節になると思われる。したがって, 食中 毒流行の強弱を考之る場合, 上記の大きさの「集団 值」に注目する必要がある。

食中毒流行の時系列変化を観察することも重要で ある。解析の結果, 食中毒の流行にも, 傾向変動お よび季節変動が認められている。興味ある点は, 傾 向変動の上昇期と下降期により, 季節変動に相違が ある点である。したがって，「集団值」だけでなく， 流行数および患者数の時系列変化も比較考察し, 人 間行動科学面から食中毒流行の理論疫学的解析が必 要である。

\section{要 約}

厚生省発行の食中毒統計1952 1988年，37年間を 資料として使用し，「集団值」なる疫学的統計值を求
め, 理論疫学的有用性および有効性について検討し, 次の結果を得た。

1. 集団值の分布は，正規型の右半分を示すような L字型を呈する。

2. 集団值を对数正規変換あるいは平方根正規変換 した值は，近似的に正規分布する。

3. 最小二乗法による解析の結果, 食中毒流行に傾 向変動および季節変動の存在が認められた。

\section{文献}

1）厚生省大臣官房局統計情報部編：食中毒統計, 厚生統計協会, 1952-1988.

2 ) KohzaKi, K. Kohzaki, R. Fukuoka, H. Kane. Ko, S. WaKi, M. \& Murata, M. : Epidemiology of Food Poisoning-Kanagawa Prefecture In Japan-, Proceeding of the $5 \mathrm{t} \mathrm{h}$ Congress FAVA, 48-50, Malaysia, 1986.

3 ) 立川 清：新・衛生統計学, 390-461, 第一出 版, 東京, 1974 .

4) 高橋浩一郎: 気象統計学, $1-70$, 河出書房, 東京, 1945.

5 ) 滝沢隆安：臨床デー夕の統計解析(1), 家亩診療 $257,3-10,1984$

6 ) 滝沢隆安：臨床デー夕の統計解析(2), 家畜診 療, 258,9-15, 1984.

7 ) 滝沢隆安：臨床データの統計解析(3), 家畜診 療, 257, 259, 45-53，1985.

8 ) 滝沢隆安：獣医応用統計学-一般統計解析-192206 , 学空社, 東京, 1985.

9 ) 山田俊雄：家畜伝染病診断学総論, 疫学的診 断, 28-40, 文永堂, 1955.

10）山田俊雄 ·真野 宏・三田泰弘・川口正冬 - 原 稔：食中毒の季節的異常流行について, 日獣会 誌, $11,130,1958$.

11）山田俊雄：食中毒雑考-主として病因物質不詳 の食中毒についてー日獣会誌，15，209-214， 1962.

12）山岸精実：東京府下に於ける大震災後の「腸千 フス」流行の異常季節分布の統計学的研究, 実 験医学, 22, 1537-1563, 1938. 